\title{
THE PREPOSITION NGANTI
}

IN JAVANESE LANGUAGE

\author{
ARI WULANDARI \\ Humanities Science, Cultural Science Faculty \\ Gadjah Mada University, Yogyakarta
}

\begin{abstract}
This essay is under auspice of structural linguistics, which is mean to describe the preposition nganti in Javanese language, understanding, how to use, what kind of categorial coconstituent which is determined the presence, what is function, and what semantic role of prepositional phrases. Therefore, this essay uses descriptive qualitative method and a contact approach. This essay shows the result the presence of the preposition nganti in the sentence is not determined by the filler predicates category, but is determined by the coconstituent category which can be seen from the use. Categorical types of constituents that determine the presence of the preposition nganti are five categories, namely nouns (concrete, abstract), adjectives, numerals, adverbs (temporal, qualitative, size), and verbs (active, adversative). The preposition nganti function is as a boundary ending marker (time, place, number, size), a purpose marker, and an effect marker.
\end{abstract}

Key words: preposition nganti, Javanese language, structural linguistic, coconstituent, category, function, marker

\section{Introduction}

The problem examined in this essay is the use of preposition nganti function in the Java language. To discussion of the issue, need a special aspect studied, including the use of preposition nganti, categorical type that determinants preposition nganti presence and prepositional phrases nganti semantic roles. Consider sentences (1) below.

(1) Wingi adhiku nonton bal-balan nganti esuk. (Javanese) Kemarin adikku nonton sepak bola sampai pagi. (Indonesian) Yesterday my sister watching football until morning. (English)

The presence of preposition nganti 'to' in sentence (1) above is determined by the concrete nouns coconstituent category, namely esuk 'morning'. While the function of the preposition nganti in sentence (1) as a marker of the role of the deadline, i.e esuk 'morning'. 
Based on the above, this essay aims to describe how real the preposition nganti in the Javanese language, how to use, what kind of coconstituent categorical that determine the presence, what is the function, and what role semantic prepositional phrases.

This essay is expected to provide a comprehensive overview preposition nganti in the Javanese language, both the use and problematic. The whole discussion is restricted only from everyday oral conversation that occurred in Yogyakarta. Determination of the source data orally considered to represent the use of the Javanese language which is used and understood by Javanese language speakers in general.

Thus, this essay is limited to the following discussion. First, describe the preposition nganti in the Javanese language. Second, the use of preposition nganti. Third, the type of categorical coconstituent that determines the presence of preposition nganti. Fourth, the functions use of preposition nganti. Finally, this research produced the conclusion that the presence of the preposition nganti in the sentence is not determined by the filler predicates category, but is determined by the coconstituent category which can be seen from the examples of the preposition nganti. Categorical types of constituents that determine the presence of the preposition nganti there are five categories, namely nouns (concrete, abstract), adjectives, numerals, adverbs (temporal, qualitative, size), and verbs (active, adversative). The preposition nganti function usage is as a boundary marker end (time, place, number, size), a marker of purpose, and a marker effect.

\section{The Preposition Nganti}

Poerwadarminta (1953:105-110) mentions that the preposition or preposition tembung ancerancer, while Antunsuhono (1953:96) calls it tembung panggandheng or tembung lantaran. Basically the second linguist has the same opinion regarding the definition preposition is the word that connects a single word with another word. In general, linguists classify the prepositions to the class of said task or particles (Ramlan, 1980:13; Hj Omar, 1980:166; Wedhawati, 1980:20; Kridalaksana, 1980:137). Words class like these are usually not morphemes process subject and does not contain lexical meaning, but contains a grammatical meaning (Kridalaksana, 1983:21). This means that the 
preposition has only the function and meaning in syntactic structure, so Sudaryanto (1983:214-219) refer to it as non-referential words, the words class that refers to the relationship between the substance of the elements of the situation. Preposition as one type of non-referential words, sometimes called word assignment or structural words syntactically, semantically there that serves to connect in front of it constituents, i.e constituents filler predicate with constituents who was behind it or coconstituent and there are no. Structurally, prepositions and prepositional phrases functioning form that tends to fill the function of syntactic information in sentence structure of subject-predicate-object-description or subject-predicatedescription (Wedhawati, et al., 1990:1).

The preposition nganti is a preposition in the ngoko 'daily spoken' Javanese language that can be used in variety of language formal, nonformal, and literary (literature). The preposition nganti is a form of manners ngantos, but that is not discussed in this essay. The presence of preposition nganti in the sentence is not determined by the filler predicates category, but is determined by the coconstituent category. Coconstituent preposition nganti can be filled by five different types of categories, namely nouns (concrete, abstract), adjectives, numerals, adverbs (temporal, qualitative, size), and verbs (active, adversative). That is, preposition nganti present in the sentence when coconstituent form of concrete nouns, abstract nouns, adjective, temporal adverbs, qualitative adverbs, size adverbs, active verbs, and adversative verbs.

\section{The Preposition Nganti Used}

The use of preposition nganti in the Javanese language can be seen in the following sentences.

(2) Wingi aku wis nonton film kuwi nganti sore.

Kemarin aku sudah nonton film itu sampai sore.

Yesterday I was watching the movie until late afternoon.

(3) Ibu tindak Singapura wiwit dina Setu nganti Rabu minggu ngarep.

Ibu pergi ke Singapura dari Sabtu sampai Rabu minggu depan.

Mother went to Singapore from Saturday to Wednesday next week.

(4) Durene diperem nganti mateng.

Durian diperam sampai masak. 
Durian brooded until cooked.

(5) Wacanen buku iki nganti kaca pitulas!

Bacalah buku ini sampai halaman tujuh belas!

Read this book to page seventeen!

(6) Omahe Alif isih dikontrakne nganti saiki.

Rumah Alif masih dikontrakkan sampai sekarang.

Alif's house is still contracted until now.

(7) Aku wis sinau nganti bola-bali, nanging tetep durung mudheng.

Aku sudah belajar sampai berkali-kali, tetapi tetap belum paham.

I have learned through many times, but still do not understand.

(8) Yen riyaya tamune akeh banget nganti kursine kurang.

Kalau lebaran tamunya banyak sekali sampai kursinya kurang.

If Eidul Fitri visitors a lot less to his chair.

(9) Kabecikane Pak Amir ndadekne aku trenyuh nganti nangis.

Kebaikan Pak Amir membuatku terharu sampai menangis.

Mr. Amir goodness made me moved to tears.

(10) Ayo ndang bali, mengko ora kepenak yen nganti kewengen neng ndalan.

Ayo segera pulang, nanti tidak enak kalau sampai kemalaman di jalan.

Come home soon, there will not be comfortable if until late in the road.

The coconstituen nganti accompanying prepositions can be words as shown in the example sentence (2), (4), (6), (9), ie sore, mateng, saiki, and nangis. Coconstituen nganti also accompanying be a preposition phrases, as seen in the example sentence (3), (5), (7), (8), (10), i.e Rabu minggu ngarep, kaca pitulas, bola-bali, kursine kurang, and kewengen neng ndalan. In fact there should be coconstituent phrases, such as in example (11) the following sentence.

(11) Didin nyambut gawe wiwit jam pitu esuk nganti jam enem sore.

Didin bekerja dari jam tujuh pagi sampai jam enam sore.

Didin worked from seven o'clock until six o'clock.

The use of phrases jam enem sore is for the sake of absolute clarity meaning, because it cannot be used as in sentence (11a) and (11b) follows.

(11a) *Didin nyambut gawe jam pitu esuk nganti jam enem.

*Didin bekerja dari jam tujuh pagi sampai jam enam.

*Didin worked from seven o'clock until six. 
(11b) *Didin nyambut gawe jam pitu esuk nganti jam.

*Didin bekerja dari jam tujuh pagi sampai jam.

*Didin worked from seven o'clock until o'clock.

\section{The Preposition Nganti Types Categorial Determinants}

The preposition nganti coconstituent can be filled by five different types of categories, namely nouns (concrete, abstract), adjectives, numerals, adverbs (temporal, qualitative, size), and verbs (active, adversative). That is, preposition nganti present in the sentence when coconstituent form are concrete nouns, abstract nouns, adjective, temporal adverbs, qualitative adverbs, size adverbs, active verbs, and adversative verbs. Consider the sentence (2) to (10) above. Sentence (2) is an example concrete nouns coconstituent, i.e sore 'late afternoon'. Sentence (3) is examples of abstract nouns coconstituent, namely Rabu minggu ngarep 'next week Wednesday'. Sentence (4) is an example adjective coconstituent, namely mateng 'ripe'. Sentence (5) is an example numerals coconstituent, i.e kaca pitulas 'page seventeen'. Sentence (6) is an example of temporal adverbs coconstituent, namely saiki 'now'. Sentence (7) is an example of qualitative adverbs coconstituent, namely bola-bali 'repetitive'. Sentence (8) is examples of size adverbs coconstituent, i.e kursine kursi 'less seat'. Sentence (9) is an example active verbs coconstituent, i.e nangis 'cry'. Sentence (10) is an example adversative verbs coconstituent, kewengen neng ndalan 'coming home late'.

\section{The Use of Preposition Nganti Function}

The presence of preposition nganti in a sentence can mark three types of roles are as a final boundary marker, as a marker of the role of destination, and as a marker due to the role.

The preposition nganti role as a marker of the final boundary includes four issues, namely the deadline, place, number, and size. Preposition nganti act as bookmarks coconstituent deadline when filled by a word or phrase that implies a certain time, such as esuk 'morning', kawanen 'late afternoon', and so on as in the example sentence (12) below. The preposition nganti acts as a boundary marker coconstituent final place when filled by a word or phrase that contains the meaning of place, like omahe 'his house', dalan gedhe 'highway or main road' and so on as in the example sentence (13) below. The preposition nganti acts as a boundary marker when the final numbers 
coconstituent filled by word or phrase that contains the meaning of numbers, such as the lima 'five', satus 'hundred', and so on as in the example sentence (14) below. The preposition nganti acts as a boundary marker coconstituent final size when filled by a word or phrase that contains the meaning of size, such as telung ton 'three-ton', wolung trilyun 'eight trillion', and so on as in the example sentence (15) below.

(12) Apike sesuk mangkat esuk-esuk aja nganti kawanen.

Sebaiknya besuk berangkat pagi-pagi jangan sampai kesiangan.

Better get an early start tomorrow not to oversleep.

(13) Adit diterake Dani nganti omahe.

Adit diantarkan Dani sampai rumahnya.

Adit picked up Dani to his house.

(14) Anake Ben wis isa ngetung nganti satus.

Anaknya Ben sudah bisa menghitung sampai seratus.

Ben's son was able to count to one hundred.

(15) Dhuwit negara sing dikorupsi Danu nganti wolung trilyun.

Uang negara yang dikorupsi Danu sampai delapan trilyun.

Danu was corrupted state money to eight trillion.

The preposition nganti act as bookmarks goal when coconstituent was filled by word or phrase that contains the meaning of certain circumstances or nature of which is the goal of the action expressed by predicate coconstituen, such as empuk 'soft', garing 'crisp', and so on as in the example sentence (16) below.

(16) Iwake digoreng nganti garing.

Ikannya digoreng sampai kering.

Fish fried until crips.

The preposition nganti serves as a marker result if coconstituent filled by word or phrase that implies a certain result which is a result of the action expressed by predicate coconstituent, such as pucet 'pale', gosong 'burnt', and so on as in the example sentence (17) in the below.

(17) Nana nggoreng pindhang kesuwen nganti gosong.

Nana menggoreng (ikan) pindang terlalu lama sampai gosong.

Nana fry (fish) boiled too long to burn. 


\section{Conclusion}

The presence of preposition nganti in the sentence is not determined by the filler predicates category, but is determined by the coconstituent category which can be seen from these examples the use of preposition nganti. Categorical types of constituents that determine the presence of the preposition nganti there are five categories, namely nouns (concrete, abstract), adjectives, numerals, adverbs (temporal, qualitative, size), and verbs (active, adversative). The nganti preposition usage function is as a boundary marker end (time, place, number, size), a marker of purpose, and a marker effect.

\section{References}

Poerwadarminta, W.J.S. 1953. Sarining Paramasastra Djawa. Djakarta: Noordhoff-Kolff.

Antunsuhono. 1953. Ringkesaning Paramasastra Djawi. Yogyakarta: Soejadi.

Ramlan, M. 1980. Kata Depan atau Preposisi dalam Bahasa Indonesia. Yogyakarta: UP Karyono.

Hj. Omar, Asmad. 1980. Nahu Melayu Mutakhir. Kualalumpur: Dewan Bahasa dan Pustaka, Kementrian Pelajaran Malaysia.

Wedhawati. 1980. "Kata Tugas Bahasa Jawa". Yogyakarta: Proyek Penelitian Bahasa dan Sastra Indonesia dan Daerah, Daerah Istimewa Yogyakarta.

Kridalaksana, Harimurti. 1980. Kata Depan atau Preposisi dalam Bahasa Indonesia. Yogyakarta: UP Karyono.

---------. 1983. “Beberapa Prinsip Perpaduan Leksem dalam Bahasa Indonesia”. Disertasi Universitas Indonesia.

Sudaryanto. 1983. Predikat Objek dalam Bahasa Indonesia: Keselarasan Pola Urutan. Jakarta: Jambatan.

Wedhawati, et al. 1990. Preposisi dalam Bahasa Jawa. Jakarta: Departemen Pendidikan dan Kebudayaan. 